\title{
A NOTE ON THE SOURCES OF THE OLD SAXON "GENESIS."
}

It is well known that the narrative in the Anglo-Saxon Genesis $B$, which constitutes in translated form the longest existing fragment of the Old Saxon Genesis, departs considerably from the corresponding portions of the Vulgate. But it has not been clearly shown that the author had any other source, and recent opinion appears to be tending toward the view that his variations are original. This idea was long ago suggested, though not actually stated, by Sievers, who discussed the question of sources quite incidentally in his famous essay on the Heliand and the Genesis.' Sievers pointed out that, while the doctrine of the creation and fall of the angels (ll. $246 \mathrm{ff}$.) was a theological commonplace, and while other parts of the Genesis resembled passages in Avitus, at the same time there were significant variations from both Avitus and the commentators; and he laid stress upon certain elements which seemed peculiar to the Saxon poet. Later investigators have expressed doubt about the parallels from Avitus, and Behaghel, in a recent general survey ${ }^{2}$ of the literary relations of the Genesis, speaks with some assurance of the independent imagination of the author, adding that he has not been proved to have made use of any sources outside of the Bible. This opinion, then, appears to be becoming current doctrine on the subject, ${ }^{3}$ and it may be well to inquire whether the peculiarities of the Saxon narrative are, after all, so entirely without parallel.

The feature of the story which has been oftenest designated as original is the account of the temptation and the fall. The tempter, it will be remembered, is said by the Saxon poet to have

1 Der Heliand und die angelsächsische Genesis (Halle, 1875).

2 Heliand and Genesis (1903), p. xxiii, with a reference to Siebs, $Z D P h$, XXVIII, 139.

3 Other expressions of the same opinion will be cited in the following pages. Jellinek (Haupt's Anzeiger, XXI, 220), speaking primarily of the later Vatican fragments which deal with Cain and Sodom, expresses uncertainty about the author's use of biblical commentaries. He says he could cite parallels to $11.41,75,79,124,273$, etc. : "Aber mit solchen vereinzelten Nachweisen ist doch wenig gethan."

389]

Modern PhIlology, October, 1906 
declared himself a messenger of God, and to have professed to bring Adam and Eve divine permission to eat of the forbidden tree.

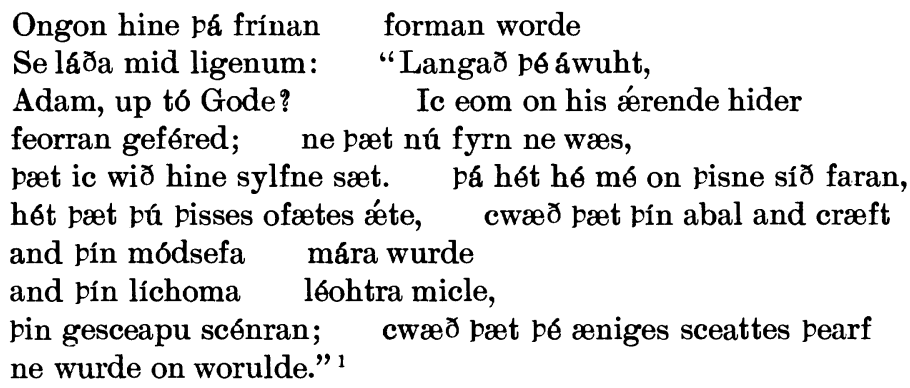

When he failed to beguile Adam, he went to Eve and urged her to avert the divine anger which Adam had incurred by doubting God's messenger and refusing to eat. If she would take the forbidden fruit herself, and persuade Adam also to taste it, all would yet be well.

Gif pú pæt angin fremest, idesa seó betste,
forhele ic incrum herran, pæt mé hearmes swá fela
Ádam gespræc, eargra worda,
týhð mé untryówða, cwyð pæt ic seó teónum georn,
gramum ambyhtsecg, nales godes engel.
Ac ic cann ealle swá geare engla gebyrdo,
heah heofona gehlidu: wæs seó hwíl pæs lang,
pæt ic geornlíce gode pegnode
purh holdne hyge, herran mínum,
dryhtne selfum: ne eom ic ðeófle gelíc. ${ }^{2}$

Thus the tempter made his appeal to the credulity of the first parents rather than to their pride, and caused them to disobey God unwittingly and in a sense innocently. The doctrine is obviously not biblical, and Sievers, finding no support for it in the commentators, pronounced it "eigenthümlich." ${ }^{3}$ Other scholars have been less cautious and have attributed it to the poet's invention. Hoenncher, in an article ${ }^{4}$ on the sources of the

1 Ll. 495 ff. The quotations are from Behaghel's text (Heliand and Genesis, p. 215).

2 Ll. $578 \mathrm{ff}$.

3 Sandras had also called attention to its peculiarity (De carminibus Anglo-Saxonicis Caedmoni adjudicatis disquisitio, p. 74).

4 Anglia, VIII, $41 \mathrm{ff}$. See particularly pp. $48 \mathrm{ff}$. Compare also Jovy's discussion of the subject in the Bonner Beiträge zur Anglistik, V. 
Genesis, while undertaking to show that Sievers was wrong in deriving any part of the poem from Avitus, insisted still more strongly than Sievers on the originality of the account of the fall; and W. P. Ker, in his admirable volume on the Dark Ages ${ }^{1}$ quoted the opinion as if it were an established fact and made it the basis of critical observations. "Both imagination and good sense," he observed, "are shown, as Sievers has brought out, in the view taken of the temptation. The ordinary theological motives, gluttony and vainglory, did not seem sufficient. The poet would not so degrade the Protoplast. Adam and Eve are beguiled by the lies of the serpent, who brings them word that the Lord has revoked his prohibition, and that for their good they are to eat of the fruit of the tree." The same implication of originality on the part of the Saxon author is found in a recent dissertation by Abbetmeyer, who remarks: "The poet, it then appears, selected the Teutonic conception of loyalty to account for the disloyalty of the first parents."

Now, while I am not prepared to say just where the Saxon writer learned his theory of the temptation, I am convinced that he did not invent it, and consequently that he is not to be credited with such originality as the foregoing comments imply. To be sure, the details of his story differ considerably from any other account of the fall that $I$ have seen. But the feature of the deception upon which Sievers and his followers lay stress, is by no means uncommon in the apocryphal documents about Adam and Eve. It is natural to conclude that the Saxon version is somehow indebted to that body of literature. In the Latin Vita Adae et Evae, edited and discussed by Wilhelm Meyer ${ }^{3}$ a few years after the appearance of Sievers' study of the Genesis, a similar deception is practiced by Satan to induce Eve, after her expulsion from the garden, to abandon her penance in the waters of the Tigris. The fiend transforms himself into an angel of

1 The Dark Ages, p. 259.

2 C. Abbetmeyer, Old English Poetical Motives Derived from the Doctrine of Sin (Minne. apolis, 1903), p.23. Elsewhere (p. 20) Abbetmeyer says of the passage in the Genesis: "The source, though much looked for, has not been found." Perhaps he means, then, that the author was influenced by the Germanic conception of loyalty, not in inventing a new theory of the fall, but in choosing among existing accounts of it.

3 Abhandl. d. konigl. bayer. Akad. d. Wiss., XIV (1878), pp. 187 ff. 
light and tells Eve that God has forgiven Adam and her and remitted their penalty. ${ }^{1} \quad$ Eve is deceived at once and comes out of the river; but Adam recognizes the Adversary and rebukes Eve for having again yielded to him. The circumstances of this temptation differ considerably from those in the Genesis, where Adam is first approached (ll. $261 \mathrm{ff}$.), and where the tempter takes the usual form of the serpent, though protesting himself to be an angel from God. But the nature of the strategy is the same in both instances, and the Saxon poet, or more probably some predecessor, may simply have transferred to the temptation in the garden the method employed by Satan, according to the $V i t a$, in the later temptation by the Tigris.

The apocryphal accounts of the earlier temptation furnish, in my opinion, some confirmation of this surmise; for they exhibit a good deal of confusion as to the form in which Satan addresses Eve when he offers her the forbidden fruit in Paradise. In the Greek Apocalypse of Moses $^{2}$ (hereafter referred to briefly as the Apocalypse) Eve, long after the expulsion, relates to her children the story of the fall. She declares that Satan appeared to her in the form of an angel, and then she describes him as answering one of her questions "out of the mouth of the serpent." ${ }^{3}$ The inconsistency apparently arises from the introduction

1 Vita, \$ 9: "Et transierunt dies xviii. tunc iratus est Satanas et transfiguravit se in claritatem angelorum et abiit ad Tigrim flumen ad Evam et invenit eam flentem. et ipee diabolus quasi condolens ei coepit flere et dixit ad eam: egredere de flumine et de cetero non plores. iam cessa de tristitia et gemitu. quid sollicita es tu et Adam vir tuus? audivit dominus deus gemitum vestrum et suscepit penitentiam vestram; et nos omnes angeli rogavimus pro vobis deprecantes dominum, et misit me, ut educerem vos de aqua et darem vobis alimentum quod habuistis in paradiso et pro quo planxistis. nunc ergo egredere de aqua et perducam vos in locum, ubi paratus est victus vester. Haec audiens autem Eva credidit et exivit de aqua Huminis et caro ejus erat sicut herba de frigore aquae. et cum egressa esset cecidit in terram, et erexit eam diabolus et perduxit eam ad Adam."

2 This Confession of Eve (Apocalypsis Mosis, $\$ \$ 15$ ff.) does not appear in the Vita, where Adam (p. 236) simply asks Eve to tell the story to the children after his death. But Meyer, believing it to have formed an episode of the earlier work from which both the Vita and the Apocalypse were derived, inserted the Greek passage (following Tischendorf's Apocalypses Apocryphae) after $\$ 41$ of the Latin text. For Meyer's discussion of the relation of the Vita and the Apocalypse see p. 206 of his article; and for evidence that a Latin text combining elements of both existed in Ireland in the tenth century see Thurneysen, Revue celtigue, VI, 104.

3 The devil first asks the serpent to help him. $\lambda \epsilon \in \gamma \epsilon \iota$ av̉

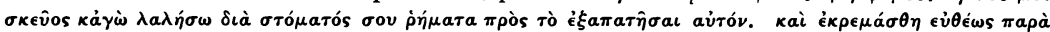

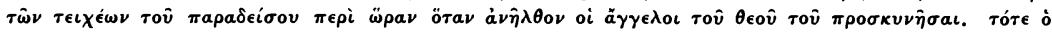

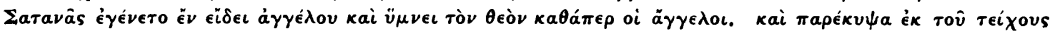


into the biblical story of the apocryphal idea of the later temptation as set forth in the Vita-just such a confusion as I have assumed to lie behind the Saxon poem. ${ }^{1}$ Except for what is implied by the angelic disguise, the motive of Eve's guilt in the Apacalypse is made substantially the same as in the biblical account. The tempter tells her that if she and Adam eat of the fruit their eyes will be opened to perceive good and evil, and that God has forbidden them to touch the tree for fear that they will become like him. But the object of the disguise itself was clearly to make Eve suppose she was dealing with a loyal messenger of the Lord, and to complete the deception Satan even joined the other angels in singing a hymn of praise to God.

The author of the Saxon Genesis, then, whether or not he wrote independently, was not the first or only authority to refuse to "degrade the Protoplast." I am inclined to believe that he did not reinvent the motive, but rather that he knew some form of the apocryphal Life of Adam and Eve. Very likely he is still to be credited with originality in his treatment of the details of the story. At all events, I have not found any other account which resembles it closely. The long speech of Satan (ll. 356 ff.), pointed out by Sievers ${ }^{2}$ as a departure from Avitus, is not only not paralleled by the Vita, but represents a different theory of the fall of the angels. ${ }^{3}$ The use by Satan of a subordinate demon

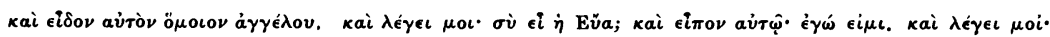

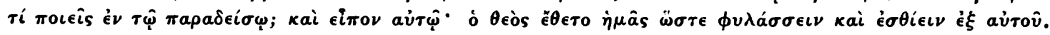

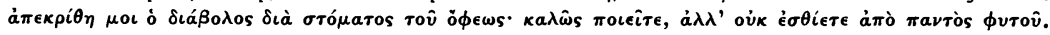

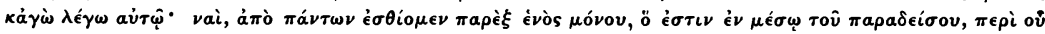

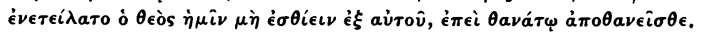

1 Meyer (p. 206) comments on this confusion in the Apocalypse. Something like it is observable in the Slavic versions of the story published later by Jagic, Abhandl. d. kais. osterreichischen Gesellsch. d. Wiss., 1893, II, $26 \mathrm{ff}$. In the first of these texts the devil appears as an angel and tempts Eve. Nothing is said of the serpent, though Satan has already instructed it to beguile Eve. In the second version, which Jagic thinks is a correction of the first account, Satan does not go to the serpent till he has talked with Eve. Gaster (Ilchester Lectures on Greeko-Slavonic Literature, p. 32) quotes a popular Wallachian version of the Confession of Eve, according to which the devil first comes as an angel and tries to beguile Eve, and after his repulse the serpent comes as an angel and prevails upon her. I cite these accounts, of course, not because I suppose them to have influenced the Saxon, but simply to show how, as I believe, the conception of the temptation in the garden was affected by the tradition about the later temptation.

2 Pp. 18 ff.

3 In the Vita Satan tells Adam that the fallen angels were expelled from heaven because they refused to worship Adam, the image of God. The Genesis, on the contrary, follows 
to tempt Eve (dyrne deofles boda, 1.490) is unlike the procedure in either the Vita or the Apocalypse. ${ }^{1}$ The long conversation between Eve and Adam when she urges him to eat the apple also finds no close parallel in these texts. ${ }^{2}$ But, on the other hand, certain elements of the Genesis which Sievers found it hard to account for may be plausibly explained by the Adam book. The delusive light which Eve saw when she had partaken of the fruit, and which disappeared soon after Adam's fall was accomplished, ${ }^{3}$ may well go back to the "great glory" described in the Apocalypse as surrounding the forbidden tree." The account of the sufferings of Adam and Eve after their expulsion (1l. $802 \mathrm{ff}$.) is not based upon the Vulgate, and Siebs has shown ${ }^{5}$ that it is not strikingly similar to the two passages cited by Sievers ${ }^{6}$ from the third book of Avitus. It is also unlikely, in my opinion, that the lines contain a reminiscence of a passage in Hilarius, as Siebs suggests, ${ }^{7}$ and it seems quite as easy to explain them as an elaboration of the situation described at the beginning of the Vita. The Latin text, to be sure, is brief and bare at this point, ${ }^{8}$ but other versions of the Adam book (as, for example, the Irish Saltair na Rann) ${ }^{9}$

the orthodox view and represents the fall of the angels as anterior to their envy of man. Meyer (p. 199) cites Augustine, De Genesi ad literam xi, 18, for the condemnation of the apocryphal account. Compare also Bonwetsch on Methodius, Gottingen Abhandlungen, N. F. VII (1903), $71 \mathrm{ff}$. A disagreement with respect to this doctrine of course constitutes no argument against the influence of the Adam book on the Genesis.

1 This situation was long ago compared by Sandras (De carminibus Anglo-Saxonicis Caedmoni adjudicatis disquisitio, p. 67) with that in another apocryphal document, The Book of Enoch (ed. Lawrence, lxviii, 61), where Gadrel is represented as the seducer of Eve.

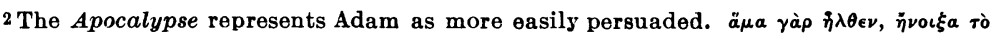

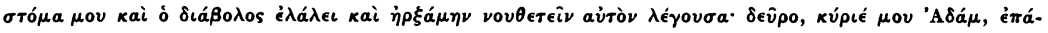

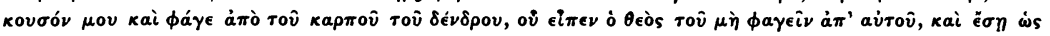

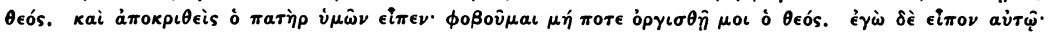

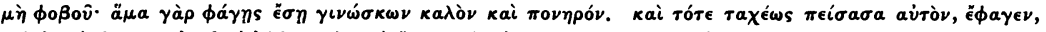

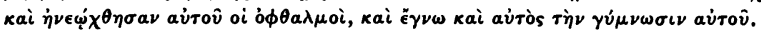

3 Ll. $600 \mathrm{ff}$., $666 \mathrm{ff}$., $772 \mathrm{ff}$.

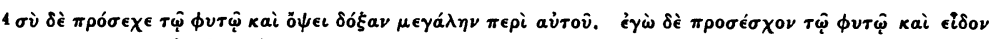

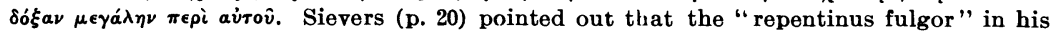
parallel passage from Avitus does not appear until after Adam's fall is accomplished, and is also not described as a "teuflischer Trug." In the Apocalypse the "great glory," which seems to be part of the tempter's device, is visible to Eve before she eats of the fruit.

5 ZDPh , XXVIII, 138, 139. 6 P. 21.

7 Sieb's's reference is to Hilarius, In Genesin ad Papam Leonem, $11.164 \mathrm{ff}$.

8 Quando expulsi sunt de paradiso, fecerunt sibi tabernaculum et fuerunt vii. dies lugentes et lamentantes in magna tristitia. post vii. autem dies coeperunt esurire et quaerebant escam ut manducarent, et non inveniebant.

9 Ll. 1469-1520 (Whitley Stokes's edition, Oxford, 1894). 
enlarge considerably upon the sufferings of Adam and Eve from hunger, thirst, and the fierceness of the elements. Finally, I think we have in Adam's words in $11.830 \mathrm{ff}$. a hint of the penance in the rivers, a conspicuous episode of the Vita which has been already referred to. ${ }^{1}$ After bewailing the sorrow that sin has brought upon himself and Eve, Adam declares himself ready to endure any pain for the sake of regaining God's favor.

Gif ic waldendes willan cúðe, hwæt íc his tó hearmsceare habban sceolde, ne gesáwe pú nó sniómor, peáh mé on sǽ wadan hété heofenes god, heonone nu pá on flód faran: nǽre hǿ firnum pæs déop, merestrǿam pæs micel, pæt his 6 mín mód getwéode, ac ic tó pám grunde genge, gif ic godes meahte willan gewyrcean. ${ }^{2}$

Unfortunately the interpolated fragment-Genesis $B$-breaks off just too soon for us to know whether the poem included an account of the penance. ${ }^{3}$

By these various resemblances, as well as by the similarity in the central motive of the temptation, I am led to believe that there is some connection between the Genesis and the body of tradition represented in the Latin Vita and the Greek Apocalypse. It remains to be said that there is no chronological difficulty in my supposition. One of the Latin manuscripts published by Meyer is earlier than the eighth century. Meyer assigns the composition of the Latin text to the fourth century, and Tischendorf dated the Apocalypse in the "saecula circa Christum natum." "The original Adam book, from which both of these were derived, Meyer holds to have been pre-Christian (probably written in Hebrew), and to this Urtext he traces various Jewish and Mohammedan legends ${ }^{5}$

1 See p. 392, above.

2 Hoenncher (Anglia, VIII, 55) suggested a relation between these lines and the Middle English Canticum de creatione, which is now known to be based upon the apocryphal Life of Adam.

3 In the later fragments of the Old Saxon Genesis there are also apocryphal elements, such as the references to the "children of Cain" (1l. $807 \mathrm{ff}$.) and to the battle between Enoch and Antichrist (11. $879 \mathrm{ff}$.). The first of these, though not found, I think, in either the Vita or the Apocalypse, appears elsewhere in documents derived from the Adam book. Compare the Irish Saltair na Rann, 11.2389 ff., for the "clann Cain."

4 See Meyer's introduction for all these matters.

5 For the Mohammedan stories in question see Weil, Biblische Legende der Musselmän. ner, p. 20. 
in which Satan is said to have tempted Eve in the form of an angel. The apocryphal story, then, was widely known long before the time of the Saxon poet, who is now supposed to have written after the author of the Heliand. Its later influence is apparent in various literatures of mediaeval Europe, and Meyer brought together in his introduction ${ }^{1}$ a considerable list of versions. But none of the vernacular texts cited by him is as early as the probable date of the Old Saxon poem, which furnishes, if my argument be accepted, an interesting bit of additional testimony to the spread of the tradition.

\section{Harvard University}

F. N. Robinson

1 See p. 209 ff. The Irish Saltair na Rann, to which I have several times referred, was not published till after Meyer's article. See Stokes's edition, Anecdota Oxoniensia, 1892, and Thurneysen's remarks, Revue celtique, VI, $114 \mathrm{ff}$. It is a document of the tenth century. A later prose redaction from the Lebor Brecc was published by MacCarthy in the Todd Lecture Series of the Royal Irish Academy, III, pp. 29 ff. The narrative in the Saltair is not close enough to that in the Genesis to suggest a direct relation between the two. 